\title{
EVALUATION OF THE QUALITY OF TWO DIFFERENT ARTIFICIAL PASTURES AND THEIR EFFECTS ON THE PERFORMANCE OF GRAZING BEEF ANIMALS
}

\author{
Mevlut TURK*, Sebahattin ALBAYRAK, Yalcin BOZKURT \\ Suleyman Demirel University, Faculty of Agriculture, Department of Field Crops, Isparta, TURKEY \\ *Corresponding author: mevlutturk@sdu.edu.tr
}

Received: 02.04.2014

\begin{abstract}
This research was conducted to determine the feeding quality of different artificial pastures and their effects on animal performance from the years 2010 to 2012. For this purpose, two different artificial pastures were established, each one covered 1.5 ha area during the first year of the research. The mixtures of the pastures used were as follows: Pasture 1 (P1): Medicago sativa L. $(20 \%)+$ Bromus inermis L. (40\%) + Agropyron cristatum L. (30\%) + Poteriumsanguisorba (10\%); Pasture 2 (P2): Medicago sativa L. (15\%) + Onobrychis sativa Lam. (15\%) + Agropyron cristatum L. (35\%) + Bromus inermis L. (35\%). The grazing was conducted in the second and the third years of the research. Twenty Holstein male calves with 6 months old were assigned to the experimental areas randomly, each pasture containing 10 animals. Forage samples were collected from grazing and non-grazing areas once every 15 days during the grazing seasons. Concurrently with forage sampling, liveweight gains of animals were also obtained. The dry matter (DM) yield, crude protein (CP), acid detergent fibre (ADF), neutral detergent fibre (NDF) contents, in vitro dry matter digestibility (IVDMD) were determined on the forage samples collected from grazing and non-grazing areas. The results showed that as grazing season advanced forage quality was declined in both pastures. The CP content and IVDMD were decreased with advancing growth stages in grazing and non-grazing areas of two pastures. The ADF and NDF contents were increased with advancing growth stages. There were no significant differences in the animal performances grazed on both pastures in terms of final weights, total weight gains and daily live weight gains.
\end{abstract}

Keywords: Animal performance; dry matter yield; forage quality; grazing; liveweight gain.

\section{INTRODUCTION}

The most important problems of raising livestock are not only the shortage of feed stuff but also the quality of forage that can be supplied in many countries with continental climate. Rangelands and harvest residue have a significant role in extensive animal husbandry in Turkey, due to the shortage of rangelands. Therefore, rangelands have substantial importance for animal production, especially during crop growing season because there are no artificial pastures or feed resources for extensive animal husbandry during this period.

In order to establish artificial pasture to produce sufficient and good quality feed in completely damaged vegetation is a suitable choice (Vallentine, 1989; Altin et al., 2005). In most situations, dryland pastures best comprised a simple mixture containing two and three species having similar palatability, season of growth, grazing tolerance, drought tolerance and rare cases of regrowth (Holzworth et al., 2003). Alfalfa (Medicago sativa L.), sainfoin (Onobrychis sativa Lam.), or other legumes planted in mixtures with grasses, provide nitrogen to increase yield and nutritive values of the entire mixture. However, it is sometimes difficult to keep legumes in the mixture because of their high palatability (Holzworth and Weisher, 2010). Alfalfa, crested wheatgrass and smooth brome cultivar would be suited for use in binary grass-alfalfa mixtures for dryland hay production (Berdahl et al., 2001).

Forage quality can be defined as the relative performance of animals (Buxton et al., 1996). In general, higher levels of cell-soluble, crude protein and minerals are considered as criteria for higher nutritive quality. These components of forage decline substantially with the advanced plant growth and reach the lowest level when plants become dormant (Koc and Gokkus, 1994) in all steppe vegetation. The changing trend of nutritive component of forage shows great differences among range types because the timing and length of growing season differ among them due to climate (Holechek et al., 2004). Most plants show a similarity in declining nutrient composition with advancing development towards maturation (Rao et al., 1973; Stubbendieck and Foster, 1978; Rebole et al., 2004; Turk et al., 2014). 
Bozkurt (2012) reported about the superior performance of Holstein cattle compared to other some local and European breed cattle and concluded that under the Mediterranean conditions Holstein cattle were better suited to the feedlot beef systems than other local and some European type cattle. The live weight gain of grazing animals decreases parallel to the declining forage quality. Therefore, it is essential to give supplemental feed to grazing animals in order to maintain live weight gain after plants begin drying due to summer dormancy (Koc et al., 2014).

The objective of this research was to determine the feeding quality of different artificial pastures and monitor their effects on animal performance in the Mediterranean climatic conditions.

\section{MATERIALS AND METHODS}

\section{Experimental location}

This study was carried out at Suleyman Demirel University Research Farm in Isparta Province $\left(37^{\circ} 45^{\prime} \mathrm{N}\right.$, $30^{\circ} 33^{\prime} \mathrm{E}$, elevation $1035 \mathrm{~m}$ ) located in the Mediterranean region of Turkey on three consecutive years of 2010 and 2012. The total precipitation and average temperature data for the experimental area are given in Figures 1 and 2. The major soil characteristics of the research area, determined based on the method described by Rowell (1994), were as follows: The soil texture was clay loam, the organic matter was $1.3 \%$ as determined using the Walkley-Black method, the lime was $7.1 \%$ as determined using a Scheibler calcimeter, the total salt was $0.29 \%$, the exchangeable $\mathrm{K}$ was $122 \mathrm{mg} \mathrm{kg}^{-1}$ by $1 \mathrm{~N} \mathrm{NH}_{4} \mathrm{OAc}$, the extractable $\mathrm{P}$ was $3.3 \mathrm{mg} \mathrm{kg}^{-1}$ by $0.4 \mathrm{~N} \mathrm{NaHCO}_{3}$ extraction, and the $\mathrm{pH}$ of a soil-saturated extract was 7.7. The soil type was calcareous fluvisol (Akgul and Basayigit, 2005).

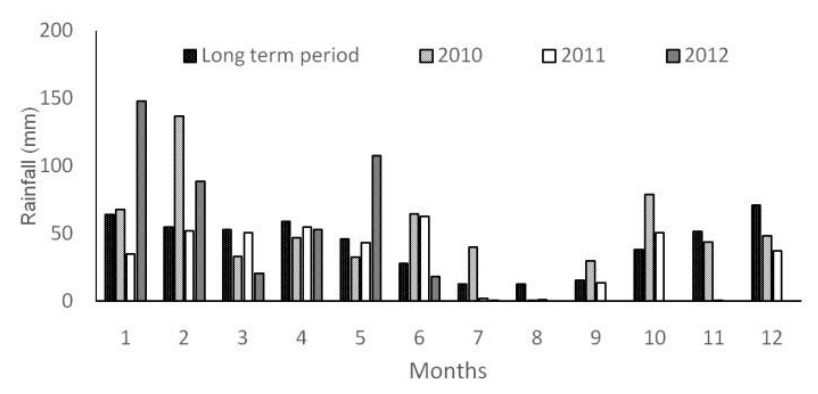

Figure 1. Rainfall values for individual experimental years and over the long term.

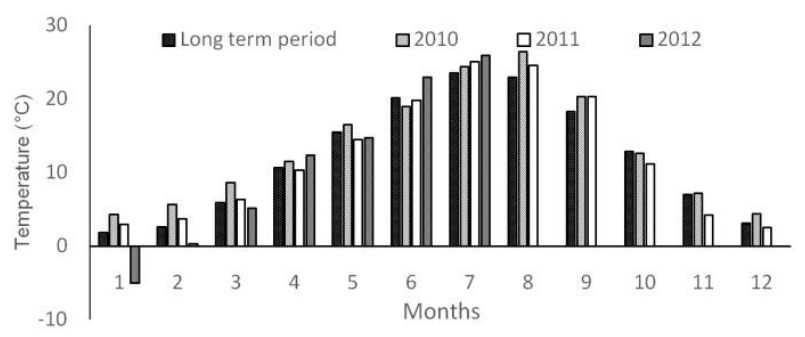

Figure 2. Temperature values for individual experimental years and over the long term.

\section{Animal Management}

In order to monitor animal performance, a total of 20 Holstein male calves with an average 6 months old were included and allocated evenly to two artificially established pastures in the experiment which lasted for 90 days in 2011 and 2012. The same breed and the same number of animals were used in both years. Animals were initially weighed at the beginning of the experiments and were randomly divided according to their weights into two grazing groups. Each group was weighed and monitored on a fortnightly basis, using electronic weighing scale (True-Test 2000 SmartUnit). The animals were turned out to pasture for grazing on the $1^{\text {st }}$ of May and the grazing was terminated on the $1^{\text {st }}$ of August each year. The free access of the animals to water and salt was available throughout the experimental period.

\section{Pasture Management}

For the establishment of artificial grazing land, 3 ha pasture land was chosen adjacent to the university farm and cultivated in March 2010 with two different botanical compositions. Pasture 1 (P1) was composed of Medicago sativa L. $(20 \%)+$ Bromus inermis L. $(40 \%)+$ Agropyron cristatum L. $(30 \%)+$ Poterium sanguisorba $(10 \%)$; and Pasture 2 (P2) had mixtures of Medicago sativa L. (15\%) + Onobrychis sativa Lam. (15\%) + Agropyron cristatum L. $(35 \%)+$ Bromus inermis L. (35\%), respectively. In first year, cutting and maintenance applications were made. Pastures were harvested twice during the end of June and beginning of October in 2010. Animal grazing applications were performed in the second and the third year of the study since the first year covered only the establishment of the artificial pastures.

In order to monitor chemical composition changes in pastures, 4 non-grazed areas within each pasture were established and fenced with wires by $4 \times 3 \mathrm{~m}$ size and grass samples were collected by using $0.5 \mathrm{~m}^{2}(0.5 \times 1 \mathrm{~m})$ quadrats fortnightly from May to August each year. The dry matter (DM) yield, crude protein (CP), acid detergent fibre (ADF), neutral detergent fibre (NDF) contents, in vitro dry matter digestibility (IVDMD) were determined as well.

After the harvest, samples were dried at $70{ }^{\circ} \mathrm{C}$ for 48 $\mathrm{h}$, and weighed. The dried samples were reassembled and ground to pass through a 1-mm screen. The crude protein (CP) content was calculated by multiplying the Kjeldahl nitrogen concentration by 6.25 (Kacar and Inal, 2008). The acid detergent fiber (ADF) and neutral detergent fiber (NDF) concentrations were measured according to methods from Ankom Technology. Tilley and Terry's (1963) methods were used to determine in vitro dry matter digestibility (IVDMD) of samples.

\section{Statistical analysis}

A randomized complete block experimental design was used in this study. General Linear Model (GLM) procedure was applied for the statistical analysis of the data by using Minitab16 statistical software programme and for the data obtained from animal experiment, initial weight and age were taken as covariates to eliminate the 
weight and age differences at the start of the experiment (Minitab,2010).In statistical analysis, the average of twoyear data was taken into account since the data related to animal and pastures were collected after the establishment of the artificial pastures.

\section{RESULTS AND DISCUSSION}

\section{Dry Matter Yield and Forage Quality}

The results of the variance analysis showed that the effects of the years, pasture types, grazing and sampling times on all investigated traits were significant (Table 1). The highest DM yields of non-grazed areas were determined in May 30 and June 15 in P1 and P2, respectively (Figure 3). The DM yields of grazed areas in both pastures decreased linearly during the grazing season. There was a quadratic relationship between DM yield and sampling times in non-grazed areas as opposed to expectation that the concentration of DM linearly increases with advancing stages of maturity (McDonald et al., 1995; Sankhyan et al., 1999). The DM yield increased until the end of May and reached the highest value (11.78 $\mathrm{t} \mathrm{ha}^{-1}$ ) in May 30 in non-grazed area of P 1 (Figure 3). This may be due to the continued growth of the plant as expected. The DM yield started to decrease in June 15 due to drying plants. In the non-grazed area of P 2, increase in DM yield lasted until June 15, after June 30 it began to decrease due to drying plants. However, DM yield was decreased linearly throughout the grazing season in the grazed areas of $\mathrm{P} 1$ and $\mathrm{P} 2$ due to the consumptions by animals. Those variations caused significant interaction between pasture types $\times$ grazing $\times$ sampling times for DM yield. Decreases in DM yields due to grazing have been reported in numerous studies (Karslı et al., 2003; Gokkus et al., 2005). DM yields of non-grazed areas were higher than those of grazed areas in the present study as expected. The DM yield of P2 was higher than that of P1. The reason for this difference is Onobrychis sativa in mixture of P2. Alfalfa, crested wheatgrass and smooth brome which types of both pastures are already suitable for arid rangelands (Altin et al., 2005). However, although sainfoin is not very suitable for long-term artificial pastures, it showed better performance than burnet.

Table 1. Results of analysis of variance and mean squares of the traits determined

\begin{tabular}{|c|c|c|c|c|c|c|}
\hline Sources of variations & df & $\begin{array}{l}\text { Dry Matter } \\
\text { (DM) Yield }\end{array}$ & $\begin{array}{l}\text { Crude } \\
\text { Protein } \\
\text { (CP) }\end{array}$ & NDF & ADF & IVDMD \\
\hline Block (year) & 6 & $11231^{* * *}$ & $0.015^{\mathrm{ns}}$ & $3.16^{* *}$ & $1.798^{* *}$ & $0.82^{\mathrm{ns}}$ \\
\hline Year & 1 & $258766^{* *}$ & $88.812^{* *}$ & $280.59^{* *}$ & $56.754^{* *}$ & $102.09^{* *}$ \\
\hline Pasture type (P) & 1 & $2897919^{* *}$ & $1.051^{* *}$ & $103.44^{* *}$ & $328.509^{* *}$ & $409.54^{* *}$ \\
\hline Grazing $(\mathrm{G})$ & 1 & $14069012^{* *}$ & $3.745^{* *}$ & $23.21^{* *}$ & $2.870^{* *}$ & $198.76^{* *}$ \\
\hline Sampling Times (ST) & 6 & $1294804^{* *}$ & $291.814^{* *}$ & $1278.55^{* *}$ & $780.733^{* *}$ & $1424.31^{* *}$ \\
\hline $\mathrm{P} \times \mathrm{G}$ intr. & 1 & $185985^{* *}$ & $0.047^{\mathrm{ns}}$ & $24.21^{* *}$ & $7.959^{* *}$ & $3.72^{\mathrm{ns}}$ \\
\hline $\mathrm{P} \times \mathrm{ST}$ intr. & 6 & $106535^{* *}$ & $0.227^{* *}$ & $0.97^{\mathrm{ns}}$ & $0.559^{\mathrm{ns}}$ & $1.06^{\mathrm{ns}}$ \\
\hline G x ST intr & 6 & $675914^{* *}$ & $0.464^{* *}$ & $5.81^{* *}$ & $2.759^{* *}$ & $8.57^{\text {** }}$ \\
\hline Px Year & 1 & $76671^{\text {** }}$ & $3.874^{* *}$ & $16.50 * *$ & $0.081^{\mathrm{ns}}$ & $1.53^{\mathrm{ns}}$ \\
\hline G x Year & 1 & $23961^{* *}$ & $1.335^{* *}$ & $13.85^{* *}$ & $0.101^{\mathrm{ns}}$ & $1.57^{\mathrm{ns}}$ \\
\hline ST x Year & 6 & $15638^{* *}$ & $0.545^{* *}$ & $0.22^{\mathrm{ns}}$ & $0.255^{\mathrm{ns}}$ & $0.13^{\mathrm{ns}}$ \\
\hline $\mathrm{P} \times \mathrm{G} \times \mathrm{ST}$ intr. & 6 & $28726^{* *}$ & $0.031^{\mathrm{ns}}$ & $1.99^{\mathrm{ns}}$ & $0.866^{\mathrm{ns}}$ & $1.18^{\mathrm{ns}}$ \\
\hline$P \times G \times$ Year intr. & 1 & $63^{\mathrm{ns}}$ & $0.007^{\mathrm{ns}}$ & $1.97^{\mathrm{ns}}$ & $0.039^{\mathrm{ns}}$ & $0.05^{\mathrm{ns}}$ \\
\hline P x ST x Year intr. & 6 & $10636^{* *}$ & $0.042^{\mathrm{ns}}$ & $0.06^{\mathrm{ns}}$ & $0.156^{\mathrm{ns}}$ & $0.00^{\mathrm{ns}}$ \\
\hline G x ST x Year intr. & 6 & $18267^{* *}$ & $0.046^{\mathrm{ns}}$ & $0.51^{\mathrm{ns}}$ & $0.150^{\mathrm{ns}}$ & $0.05^{\mathrm{ns}}$ \\
\hline P x G x ST x Year int. & 6 & $1376^{\mathrm{ns}}$ & $0.001^{\mathrm{ns}}$ & $0.10^{\mathrm{ns}}$ & $0.160^{\mathrm{ns}}$ & $0.00^{\mathrm{ns}}$ \\
\hline Error & 162 & 1144 & 0.027 & 0.75 & 0.346 & $0.77^{\mathrm{ns}}$ \\
\hline
\end{tabular}

df: degrees of freedom, ns: not significant, ${ }^{*} \mathrm{P}<0.05$ and ${ }^{*} * \mathrm{P}<0.01$.

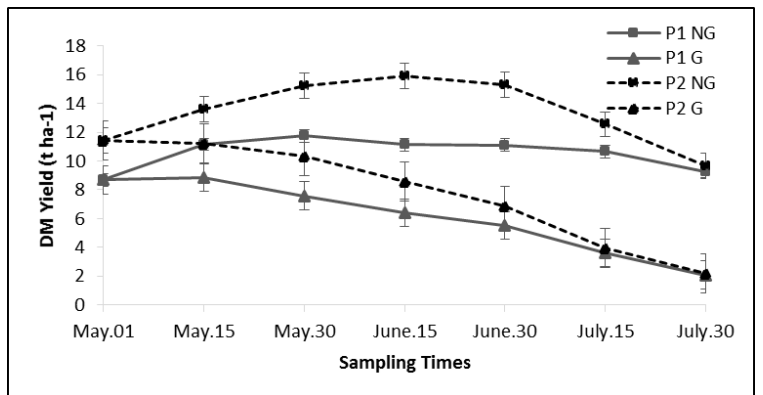

Figure 3. Seasonal variation of DM yields of two different artificial pastures (P1:Pasture 1, P2:Pasture 2, NG: Non grazing, G:Grazing).
The effects of the years, pasture types, grazing and sampling times on CP contents were significant (Table 1). The CP contents decreased linearly in grazed and nongrazed areas in both pastures. The highest CP contents were obtained from beginning of the grazing season while the lowest CP contents were determined at end of the grazing season (Figure 4). Statistically significant interactions between pasture types $\times$ sampling times and grazing $\times$ sampling times were found for $\mathrm{CP}$ ratios (Table 1). These interactions indicated that harvesting stage affected CP ratios differently according to the different pastures and grazing. The $\mathrm{CP}$ contents were decreased linearly throughout the grazing season in grazed and nongrazed areas of P1 and P2 (Figure 4). Maturity stage at 
harvest is the most important factor determining forage quality. Besides $\mathrm{N}$, and hence protein, most minerals, decline with advancing plant development. Other reports also support that the $\mathrm{CP}$ contents decreases by advancing stage of maturity (Koc et al., 2000; Rebole et al., 2004), suggesting that animals should be supplemented with protein sources, especially towards the end of the grazing season. As a result of this process, forage quality lessens substantially towards the end of growing season. The CP ratios of the grazed areas were higher than that of nongrazed areas in the present study. This could be associated with the continued re-growth of the plants in grazed areas because young plant tissues are more nutritious than dead or mature plant (Lyons et al., 1996). The CP ratio of P2 was higher than that of P1. The reason for this was that legume rates of pastures were different. Legumes are rich in terms of protein concentration (Altin et al., 2011). Pasture 1 have 20\% legume ratio while Pasture 2 have $30 \%$ legume ratio in the present study.

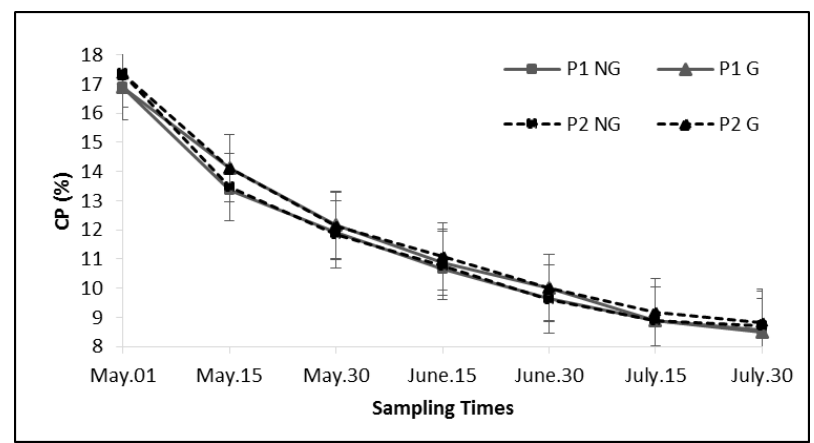

Figure 4. Seasonal variation of $\mathrm{CP}$ ratios yield of two different artificial pastures (P1:Pasture 1, P2:Pasture 2, NG: Non grazing, G:Grazing).

The effects of the years, pasture types, grazing and sampling times on $\mathrm{ADF}$ and NDF contents were significant (Table 1). The NDF and ADF contents increased linearly in grazed and non-grazed areas in both pastures. The lowest NDF and ADF contents were obtained from beginning of the grazing season while the highest NDF and ADF contents were determined at end of the grazing season (Figures 5 and 6). The effects of pasture types $\times$ grazing and grazing $\times$ sampling times interactions on $\mathrm{ADF}$ and $\mathrm{NDF}$ contents were found statistically significant $(\mathrm{P}<0.05)$. The reason for this, differences are the changes in the ADF and NDF rates. Acid detergent fiber and NDF contents were increased linearly during the grazing season (Figures 5 and 6). This could be explained by the decrease in proportion of leaves and the increase of the stems proportion with advanced maturity. Because, $\mathrm{ADF}$ and NDF contents of stems is higher than the leaves. Similar results were reported by Karslı et al. (2003), Kaya et al. (2004), Erkovan et al. (2009), Turk et al. (2007), Albayrak et al. (2009). The trends in ADF and NDF contents with increasing maturity are normally the reverse of protein (Rebole et al., 2004). Young plant cells have the primary cell wall, but also the secondary cell wall occurs with maturing. This causes being the more fibrous of mature plants (Arzani et al.,
2004). ADF and NDF contents of non-grazed areas were higher than those of grazed areas in the present study. This could be explained by the continued re-growth of the plants in the grazed areas. The ADF and NDF contents of P2 were higher than those of P1. Plants with mature structural carbohydrates (cellulose, hemicellulose, lignin) increases (Arzani et al., 2001). As a result, decrease in proportion of leaves and the increase of the stems proportion with advanced maturity causes a decrease in feed quality (Lacefield et al., 1999; Linn and Martin, 1999).

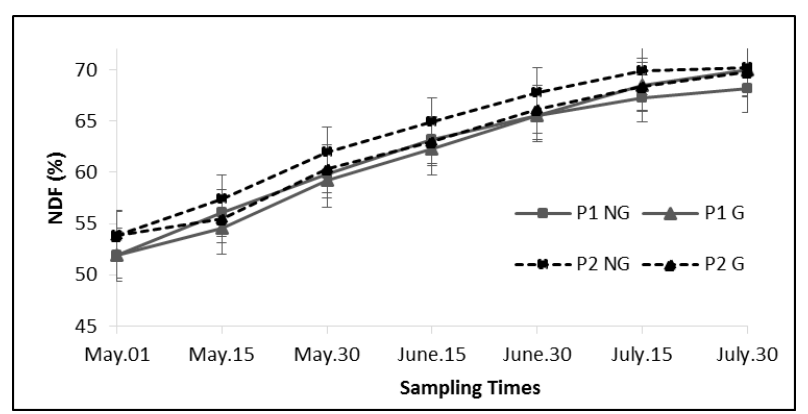

Figure 5. Seasonal variation of NDF contents of two different artificial pastures (P1:Pasture 1, P2:Pasture 2, NG: Non grazing, G:Grazing).

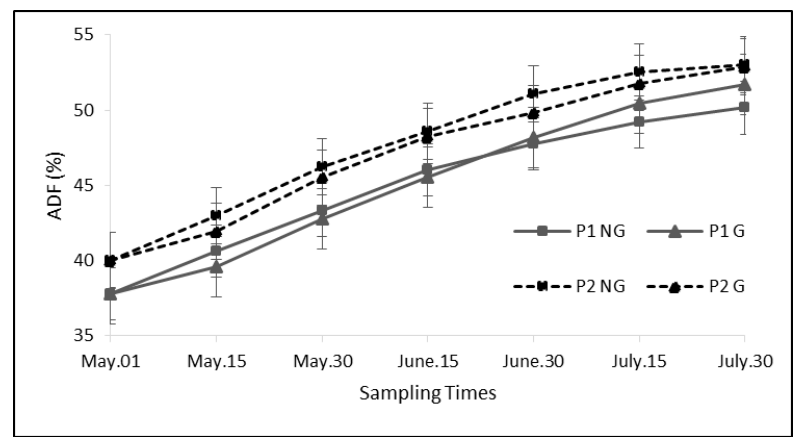

Figure 6. Seasonal variation of ADF contents of two different artificial pastures (P1:Pasture 1, P2:Pasture 2, NG: Non grazing, G:Grazing).

The effects of the years, pasture types, grazing and sampling times on IVDMD were significant (Table 1). The IVDMD was decreased throughout the grazing season in grazed and non-grazed areas of P 1 and P 2 (Figure 7). Similar results were reported by Horney et al. (1996), Hitz and Russell (1998), Karsli et al., (1999). The reason for this decrease in digestibility of plants is the increase in the lignin content (Jung and Vogel, 1992; Van Soest, 1982). The decrease in IVDMD resulted from the increase structural tissues in stems (Arzani et al., 2004). Pinkerton (1996) stated that there is a close relationship between digestibility and cell wall structure. Fiber content is increased as the plants grow, the digestibility decreases (Erfanzadeh, 2001). Overall, IVDMD varies depending on crude cellulose levels in its structure. Digestibility of plenty of leafy green forage is very high, whereas the increase of the stems proportion with advanced maturity causes a decrease digestibility (Aksoy and Yilmaz, 2003). 
The IVDMD of legumes are higher than others. Therefore, IVDMD content of $\mathrm{P} 2$ was higher than that of $\mathrm{P} 1$.

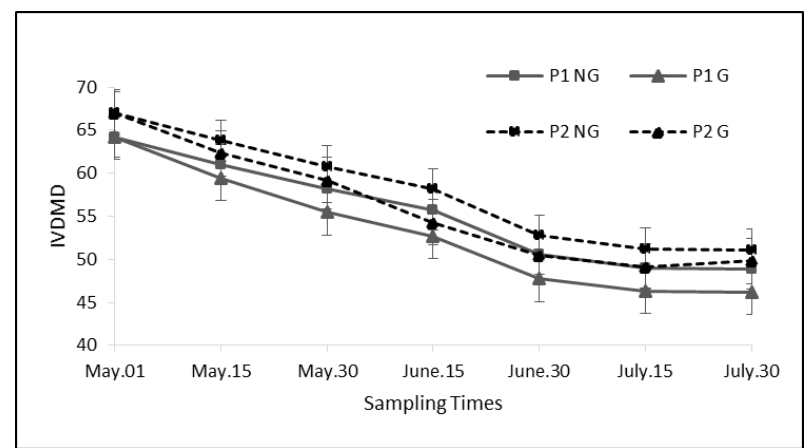

Figure 7. Seasonal variation of IVDMD of two different artificial pastures (P1:Pasture 1, P2:Pasture 2, NG: Non grazing, G:Grazing).

\section{Animal Performance}

Animal live weights were increased during the grazing season in both pastures and years (Figure 8). It was observed that these increases were greater until July 15, then these increases slowed down in both years.

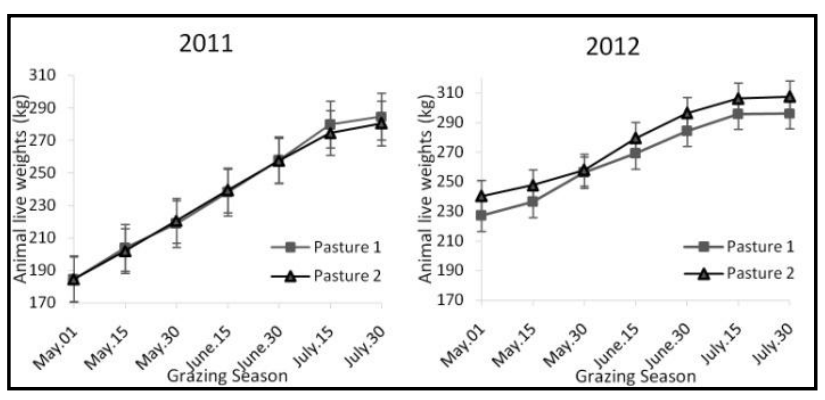

Figure 8. Animal live weights throughout the grazing season determined in 2011 and 2012 years.

There were no significant $(\mathrm{P}>0.05)$ differences between pasture types in final weight $(\mathrm{FW})$, total weight gain (TWG) and daily live weight gain (DLWG) (Figure 8). In respect to performance of animals in pasture types, the final weights were 284.7 and $280.5 \mathrm{~kg}$ for P1 and P2 in 2011, 296.2 and $307.4 \mathrm{~kg}$ for P1 and P2 in 2012, respectively. The average total weight gains 100.1 and $95.9 \mathrm{~kg}$ for P1 and P2 in 2011, 69.1 and $68.1 \mathrm{~kg}$ for P1 and $\mathrm{P} 2$ in 2012 and finally daily live weight gains of 1.112 and $1.066 \mathrm{~kg}$ for P1 and P2 in 2011, 0.768 and $0.746 \mathrm{~kg}$ for P1 and P2 in 2012, respectively (Table 2).

Table 2. Overall performance comparisons of animals by years and pasture types

\begin{tabular}{lcccccc}
\hline & \multicolumn{3}{c}{$\mathbf{2 0 1 1}$} & & \multicolumn{2}{c}{ 2012 } \\
\cline { 2 - 7 } & Pasture 1 & Pasture 2 & Mean & Pasture 1 & Pasture 2 & Mean \\
\hline IW & 184.6 & 184.6 & 184.6 & 227.1 & 240.3 & 233.7 \\
FW & 284.7 & 280.5 & 282.6 & 296.2 & 307.4 & 301.8 \\
TWG & 100.1 & 95.9 & 98.0 & 69.1 & 67.1 & 68.1 \\
DLWG & 1.112 & 1.066 & 1.089 & 0.768 & 0.746 & 0.757 \\
\hline
\end{tabular}

IW= Initial weight, FW= Final weight, TWG= Total weight gain, DLWG= Daily live weight gain

There were significant $(\mathrm{P}<0.05)$ differences between years in Final weight (FW), Total weight gain (TWG) and DLWG. The animals in 2011 tended to perform better than the cattle in 2012 in all parameters observed. As it is presented in Table 2, final weights of the animals in the years 2011 and 2012 were 282.6 and $301.8 \mathrm{~kg}$; the average total weight gains 98.0 and $68.1 \mathrm{~kg}$ and finally daily live weight gains of 1.089 and $0.757 \mathrm{~kg}$ respectively. The reason for the TWG and DLWG differences between years could be due to higher DM yield of pastures in 2011.

In literature, there are no many published studies on performance of different breeds and comparison on different beef production systems in the Mediterranean conditions. However, Bozkurt (2012) reported about the superior performance of Holstein cattle compared to other some local and European breed cattle and concluded that under the Mediterranean conditions Holstein cattle were better suited to the feedlot beef systems than other local and some European type cattle.

Keane et al. (1989) and Keane and More O'Ferrall (1992) reported some results on breed comparisons indicating that differences in factors such as production systems, slaughter weights and climate conditions are of great importance. Similarly, it was stated that breeds and crosses of beef cattle show distinctive differences in performance in different production systems (Bozkurt and ApDewi, 1996). Performance potential vary greatly between different breeds of cattle and different production systems. While there are certainly differences between performance of animals in growth rate, the live weight gain which can be achieved from a given area of grass or quantity of feed is similar for most breeds of animals, provided that animal is fed and managed according to its own particular requirements in its own environment (Wilkinson, 1985).

\section{CONCLUSIONS}

It can be concluded thatthe highest DM yields of nongrazed areas were determined in May 30 and June 15 in P1 and P2, respectively, while the DM yields of grazed areas in both pastures decreased linearly during the grazing season. The harvesting at the late stages caused a reduction in forage quality. The $\mathrm{CP}$ content and IVDMD decreased throughout the grazing season, while ADF and NDF contents increased in grazing and non-grazing areas in both pastures. The effects of pastures on animal performance were not significant. Animal performances were similar during both grazing seasons in both pastures and years. 
At the end of a three-year research conducted in the Mediterranean type of climatic conditions, pasture 2 (Medicago sativa L. (15\%) + Onobrychis sativa Lam. $(15 \%)+$ Agropyron cristatum L. $(35 \%)+$ Bromus inermis L. $(35 \%)$ ) can be recommended in respect for high yield and quality for the regions with similar type of climatic conditions and especially for the inner parts of the region with an altitude higher than a thousand meter.

\section{ACKNOWLEDGMENTS}

This work was financially supported by TUBITAK (Turkish Scientific and Technological Research Council, project no. 1090162).

\section{LITERATURE CITED}

Akgul M, L Basayigit.2005. Detailed soil survey and mapping of Suleyman Demirel University farming land. In: Bulletin (Fen Bilimleri Enstitusu Dergisi) 9 (3), Suleyman Demirel Universitesi, Isparta, Turkey, 54-63, available from URL: http://edergi.sdu.edu.tr/index.php/fbed/article/viewFile/822/1 $\underline{119}$

Aksoy A, A. Yilmaz.2003. Metabolizable energy values and dry matter and organic matter digestibilities of some alfalfa varieties. Journal of Agricultural Sciences, 9 (4): 440-444.

Albayrak, S., M. Turk and O. Yuksel. 2009. Effects of phosphorus fertilization and harvesting stages on forage yield and quality of woolypod vetch. Turkish Journal of Field Crops, 14(1):30-40.

Altin M, A. Gokkus, AKoc. 2005. Range and Meadow Improvement and Development. The Ministry of Agriculture and Rural Affairs, Republic of Turkey, Ankara, 1-468.

Arzani H, J. Torkan, M. Jafari, A. Nikkhah. 2001. Investigation on effects of phenological stages and environmental factors (soil and climate) on forage quality of some important range species. Iran J AgricSci 32:385 -397.

Arzani H, M. Zohdi, E. Fish, G.H. ZahediAmiri, A. Nikkhah, D. Wester.2004. Phenological effects on forage quality of five grass species. J Range Manage 57:624 -629.

Berdahl J.D., J.F.Karn, J.R. Hendrickson. 2001. Dry matter yields of cool-season grass monocultures and grass-alfalfa binary mixtures. Agron J 93: 463-467.

Bozkurt Y. 2012. Seasonal performance of different breeds of feedlot beef cattle grown under the Mediterranean conditions. Bulgarian J AgricSci 18 (3):443-445.

Bozkurt Y., I. Ap Dewi.1996. Effect of breed type, sex, birth year and season of birth and their interactions on live weight change in beef cattle. In: Bulletin 10 (13) Faculty of Agriculture, Selcuk University, Aleaddin Keykubat, Turkey, 125-140.

Buxton R.D., D.R. Mertens, D.S. Fisher.1996. Forage quality and ruminant utilization. In: Cool-Season Forage Grasses (Eds Moser, LE, Buxton DR, Casler MD), American Society of Agronomy, Crop Science Society of America \& Soil Science Society of America, Madison, Wisconsin, USA, 229-267.

Erfanzadeh R. 2001. Investigation on quality indices changes of rangeland species during two phenological stages. In: Proceedings of the 1st National Livestock and Rangeland Management Congress, Research Institute of Forests and Rangelands of Iran, Tehran, 60.

Erkovan H.I., M.K. Gullap, M. Dasci, A. Koc. 2009. Changes in leaf area index, forage quality and above-ground biomass in grazed and ungrazed rangelands of Eastern Anatolia Region. Journal of Agricultural Sciences, 15 (3): 217-223.
Gokkus A., B.H. Hakyemez, I.Y. Yurtman, T. Savas. 2005. The effects of different stocking rates on pasture hay yield and milk yield of goats in different types of pastures. Akdeniz University Journal of the Faculty of Agriculture 18: 207 212.

Hitz A.C., J.R. Russell. 1998. Potential of stockpiled perennial forages in winter grazing systems for pregnant beef cows. J AnimSci 76:404-415.

Holechek J.L., R.D.Preper, C.H. Herbel. 2004. Range Management: Principles and Practices, 5th edn. Prentice Hall, New Jersey, 1-607.

Holzworth L, J. Mosley, D. Cash, D. Koch, K. Crane. 2003. Dryland pastures in Montana and Wyoming. Montana State University Extension Service, Montana, available from URL:

http://msuextension.org/publications/AgandNaturalResource s/ EB0019.pdf .

Holzworth L.K., L.E. Wiesner. 2010. Dryland seeded pastures: management of seedings - principles of establishment and seedling year management. Publication \& Information Animal \& Range Sciences, Extension Service, Montana State University, Montana, available from URL: http://animalrangeextension.montana.edu/articles/forage/Chp t3/3-mgt-dry.htm

Horney M.R., T. DelCurto, M.M. Stamm, R.K. Bailey, S.D. Brandyberry. 1996. Early-vegetative tall fescue hay vs alfalfa hay as a supplement for cattle consuming low-quality roughages. J AnimSci 74: 1959-1966.

Jung H.J.G., K.P. Vogel. 1992. Lignification of switcgrass (Panicum virgatum) and big bluestem (Andropogon gerardii) plant parts during maturation and its effect on fibre degradability. J Sci Food Agric 59:169-176.

Kacar B, A. Inal. 2008. BitkiAnalizleri. Nobel Akademik Yayıncilik, Ankara, 1-892.

Karsli M.A., J.R.Russell, M.J. Hersom. 1999. Evaluation of berseem clover in diets of ruminants consuming corn crop residues. J AnimSci 77:2873-2882.

Karsli M.A., S. Deniz, H. Nursoy, N. Denek, H. Akdeniz. 2003. The effects of maturity on range quality and animal performance. Turk J Vet Anim Sci 27:117-124.

Kaya I, A. Oncuer, Y. Unal, S. Y1ld1z. 2004. Nutritive value of pastures in Kars district. I. Botanical and nutrient composition at different stages of maturity. Turk J Vet Anim Sci 28:275-280.

Keane M.G., G.J. More O'ferrall.1992. Comparison of Friesian, Canadian Hereford $\times$ Friesian and Simmental $\times$ Friesian steers for growth and carcass composition. AnimProd 55: 377-387.

Keane M.G., G.J. More O'ferrall, J. Connolly. 1989. Growth and carcass composition of Friesian, Limousin $\times$ Friesian and Blonde d'Aquitaine $\times$ Friesian steers. Anim Prod 48: 353 365.

Koc A, A. Gokkus.1994. Determination of basal area, botanical composition and suitable stubble height of the rangelands of Guzelyurt district, Erzurum. Turk J Agric For 18: 495-500.

Koc A, A. Gokkus, A. Bakoglu, A. Ozaslan.2000.The changing in some chemical properties of grass samples received from different sections of Palandoken pastures in grazing season, In: Proceedings of the International Animal Nutrition Congress, 4-6 September 2000, Isparta, 471-478.

Koc, A., A.Kaya, M.K.Gullap, H.I.Erkovan, M.Macit, M.Karaoğlu, 2014. The effect of supplemental concentrate feed on live weight gain of yearling heifers over grazing season in subirrigated rangelands of East Anatolia. Turk J Vet Anim Sci. 38: 278-284.

Lacefield G., J.C. Henning, M. Collins, L. Swetnam.1999. Quality hay production. Cooperative Extension Service, 
University of Kentucky, Collage of Agriculture, Lexington, available from

URL:

http://www2.ca.uky.edu/agc/pubs/agr/agr62/agr62.pdf

Linn J.G., N.P. Martin. 1999. Forage Quality Tests and Interpretations. Publication No. 02637, University of Minnesota Extension Service, Minnesota, 1-4.

Lyons R.K., R. Machen, T.D.A. Forbes.1996. Why range forage quality changes. Texas A\&MAgriLife Extension Service, Texas, USA, available from URL: http://gillespie.agrilife.org/files/2013/02/WhyRangeForageQ ualityChanges.pdf

McDonald P., R.A. Edwards, J.F.D. Greenhalgh, C.A Morgan.1995. Animal Nutrition, 5th edn. Longman Scientific and Technical, Harlow, UK, 1-607.

Minitab.2010. Minitab Reference Manual: Release 16 for Windows. Minitab Inc., State College, Pennsylvania, USA.

Pinkerton B. 1996. Forage Quality. Crop and Soil Environment Science Department, College of Agriculture, Forest, and Life Science, Clemson University, Clemson, South Carolina, 1998.

Rao M.R., L.H. Harbers, E.F. Smith, 1973. Seasonal change in nutritive value of bluestem pastures. J Range Manage 26: 419-422.

Rebole A., C.Alzueta, L.T.Ortiz, C. Barro, M.L. Rodriguez, R. Caballero. 2004. Yields and chemical composition of different parts of the common vetch at flowering and at two seed filling stages. Span J Agric Res 2: 550-557.

Rowell D.L. 1994. Soil Science: Methods and Applications. Longman Scientific and Technical, Harlow, UK, 1-350.

Sankhyan S.K., A.K. Shinde, R. Bhatta, S.A. Karim.1999. Comparison of diet and faecal collection methods for assessment of seasonal variation in dry matter intake by sheep maintained on a Cenchrusciliaris pasture. Anim Feed SciTechnol 82: 261-269.

Stubbendieck J., M.A. Foster.1978. Herbage yield and quality of threadleaf sedge. J Range Manage 31: 290-292.

Tilley J.M.A., R.A. Terry.1963. A two-stage technique for the in vitro digestion of forage crops. J Br GrasslSoc 18: 104-111.

Turk M, S. Albayrak, O. Yuksel. 2007. Effects of phosphorus fertilization and harvesting stages on forage yield and quality of narbon vetch. N Z J Agric Res 50:457-462.

Turk M, S. Albayrak, Y.Bozkurt.2014. Seasonal trends in chemical composition of different artificial pastures. Turkish Journal of Field Crops, 19(1):53-58.

Vallentine J.F. 1989. Range Development and Improvements, 3rd edn. Academic Press, Inc., San Diego, California, 1-524.

Van Soest P.J.1982.Nutritional Ecology of the Ruminant. O \& B Books Inc., Corvallis, Oregon, 1-374.

Wilkinson J.M. 1985. Beef Production from Silage and Other Conserved Forage. Longman Group Limited, London and Newyork, 1-152. 